\title{
Vådeskuddet fra Edvard Munchs revolver
}

«I den bitre avskjedstime mellom to mennesker som gjennom fire år forgjeves hadde søkt et felles grunnlag, grep hun i fortvilelse etter revolveren. Beskyttende og avvergende la han sin hånd over hennes, men skuddet gikk av og såret uopprettelig den hånden som holder paletten.»

Jacob Magne Klafstad

jklaf@broadpark.no

Sitatet over er hentet fra kunsthistoriker Eli Greves (1896-1949) beskrivelse av det som hendte i Edvards Munchs hus i Åsgårdstrand en septemberdag i 1902 (1, s. 272). Hvem som først grep etter revolveren, er usikkert. Edvard Munch (1863-1944) selv hadde ingen klar erindring om dette øyeblikket. Han skal ha uttalt: «så hadde jeg revolveren $\mathrm{i}$ hånden, hvordan jeg hadde tatt den - hva jeg ville vet jeg ikke ...» $(1$, s. 247). I Munchs journal fra Rikshospitalet 12. september
1902 står det innledningsvis: «Patienten sat igaaraftes og fingret med en revolver da et skud plutselig gikk av...» (1, s. 248).

\section{En kjærlighetshistorie}

«Tulla» (Mathilde) Larsen (1869-1942), ofte omtalt som vinhandlerens datter, møtte Edvard Munch første gang på sin 29-årsdag 10. august 1898. Munch var da 35 år gammel. De nærmeste fire årene var preget av deres turbulente forhold, som langt på vei kan beskrives som sykdomsfremkallende for dem begge. Nøkkelord: sjalusi, paranoia, rastløshet, lange reisefravær og alkoholmisbruk. Og kjærlighetssorg.

På sine etter hvert korte møter og i korre- spondansen diskuterte de til stadighet sine vanskeligheter og hadde dystre tanker om fremtiden. Tulla ønsket en total forening ekteskap. Munch mente at ekteskap for uforenlig med kunstnerlivet.

23. august 1902 mottok Munch en dramatisk melding - under et opphold i Røyken hadde Tulla fors $ø$ kt å ta sitt eget liv. «Der stod to tømte morfinflasker ved sengen» (1, s. 243). Pulsen var knapt følbar. Lokale hjelpere tvangsforsynte henne med store mengder kaffe og hun kom etter hvert til bevissthet.

Munch besøkte henne dagen etter. Hun var svært svak og lå i et halvmørkt værelse «med sitt røde hår flommende ut over

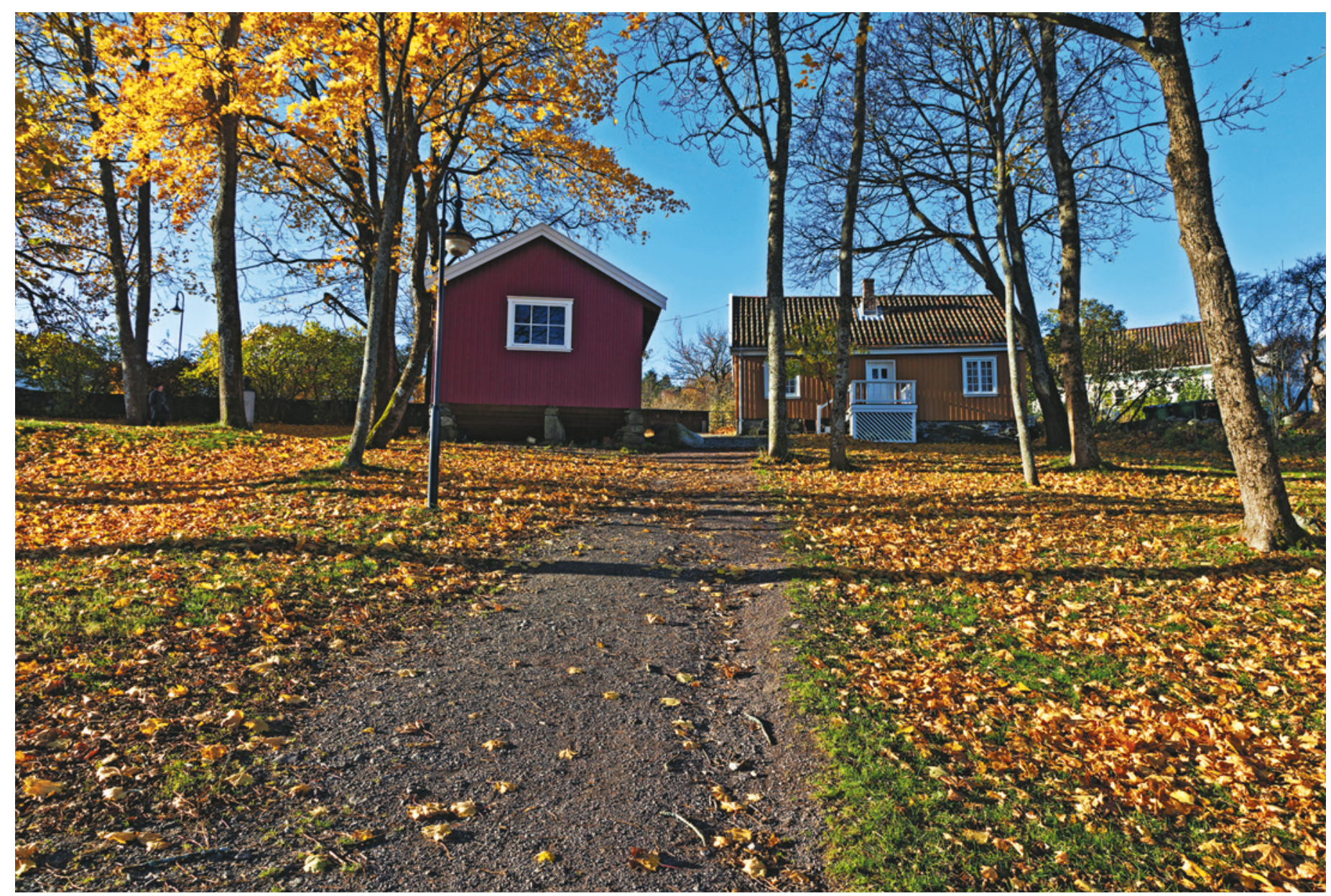

Figur 1 Edvard Munchs hus i Åsgårdstrand. Foto: Svein Grønvold/Samfoto/NTB scanpix 


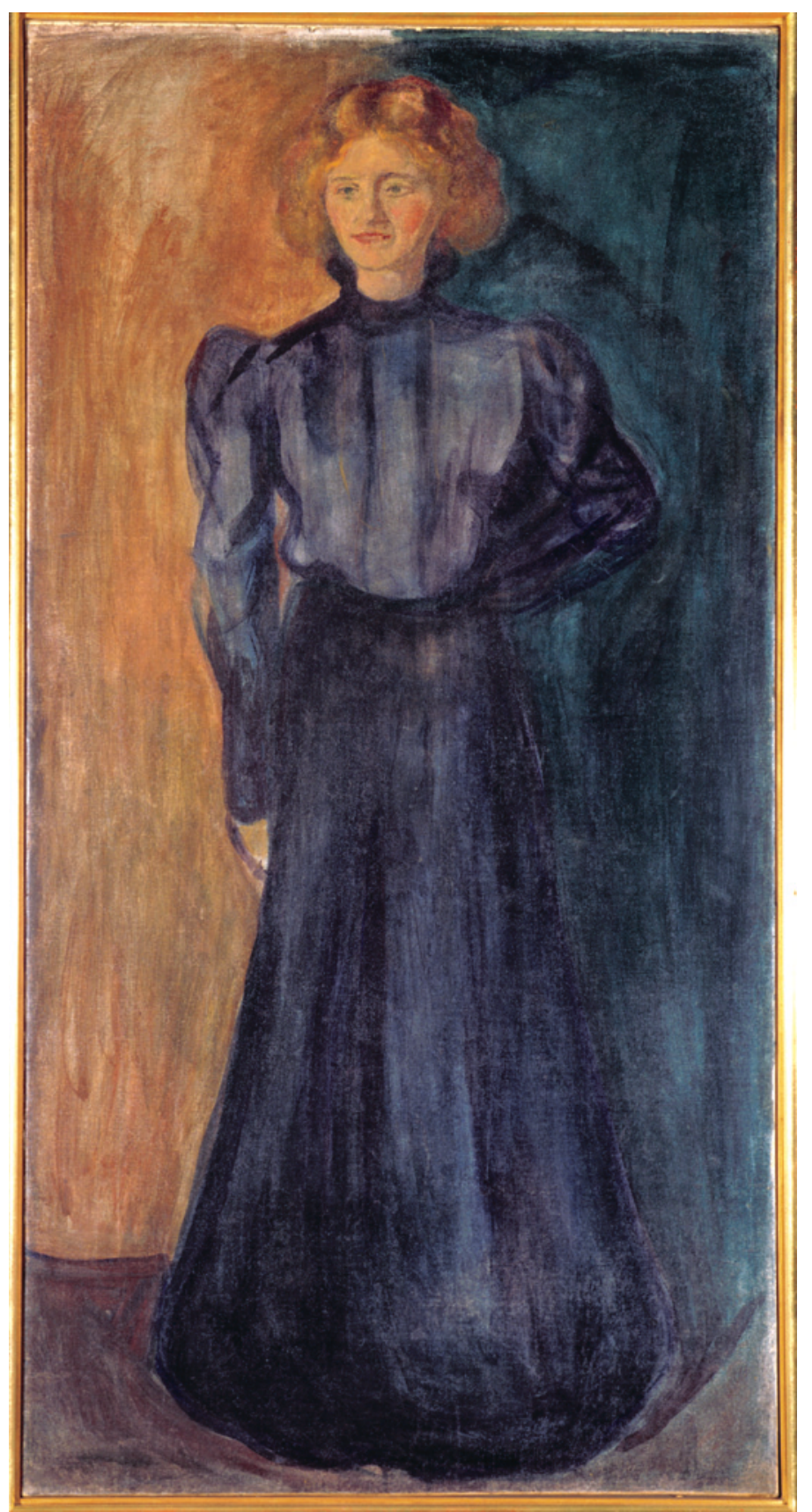

Figur 2 Edvard Munch: Tulla Larsen, 1898-99. Olje på lerret, 119,5×61 cm. Munchmuseet. Foto @ Munchmuseet

puten». Munch lovet at «det skulle bli bedre» (1, s. 244) og at han etter en kort, nødvendig reise til Berlin skulle ta henne med til Åsgårdstrand for å snakke om en felles fremtid.

Første uke av september 1902 var Munch tilbake. Tulla reiste med båt fra Røyken til Drøbak og tok inn på hotell for å falle til ro (2). De møttes så på dampskipsbryggen i Drøbak. Hun kom i siste liten før båten skulle gå til Horten. De vekslet knapt ett ord under overfarten. Den nervøse spenningen dominerte - som så ofte før.
De kom til Åsgårdstrand om kvelden, til kaldt hus (fig 1). Munch var ikke forberedt på forsoning på Tullas premisser. Tausheten hersket, og de gikk etter hvert og la seg $\mathrm{i}$ hvert sitt værelse $(1,2)$.

\section{Skytedramaet}

Neste dag spiste paret frokost, gikk ut i atelieret og så på bilder - og begynte så endelig å snakke. Munch var bekymret for hva de skulle spise - han var pengelens. Tulla ga ham hundre kroner, og han gikk ut for å handle. Litt senere kom han til- bake - uten middagsmat $(1,2)$. Han hadde kun kjøpt en flaske konjakk! En provokasjon!

Det ble ikke noe måltid den ettermiddagen. I stedet drakk Munch konjakk. Etter hvert satt han med hodet i hendene og gråt. Lyden av gråt og av konjakk som ble helt i glass var det eneste som kunne høres i flere timer - inntil det ble avfyrt et skudd. Kruttrøyken spredte seg i det lille rommet (2). Enkelthetene var uklare.

Skuddet rammet Munchs venstre hånd, som blødde voldsomt. Tulla prøvde å for- 


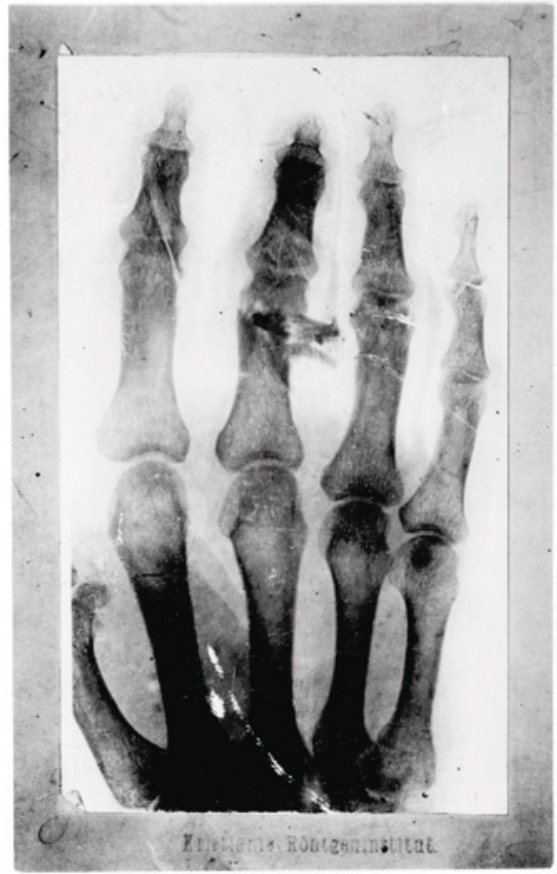

Figur 3 Røntgenogram av Edvard Munchs venstre hånd viser skade på 3. og 4. finger. Foto: Kristiania Røntgeninstitutt. Kopi i Munchmuseets arkiv

binde ham og tørket blod fra gulvet, og Munch ropte til henne at hun skulle tilkalle lege.

Dr. Wilhelm Grimsgaard (1868-1937) ankom. Han var omgangsvenn av Munch og praktiserte i Åsgårdstrand (1, 3). Legen forbandt såret og henviste Munch til Rikshospitalet i Kristiania. Munch reiste alene med dampbåten neste morgen. Han hadde store smerter, som han døyvet med konjakk.

Med vådeskuddet 11. september 1902 var det slutt på «Tulla-epoken» (fig 2). Hun kom aldri tilbake til Åsgårdstrand.

\section{Operasjonen}

I journalen fra Munchs innleggelse på Rikshospitalet 12. september 1902 beskrives skaden slik (1): «status præsens: kulen har

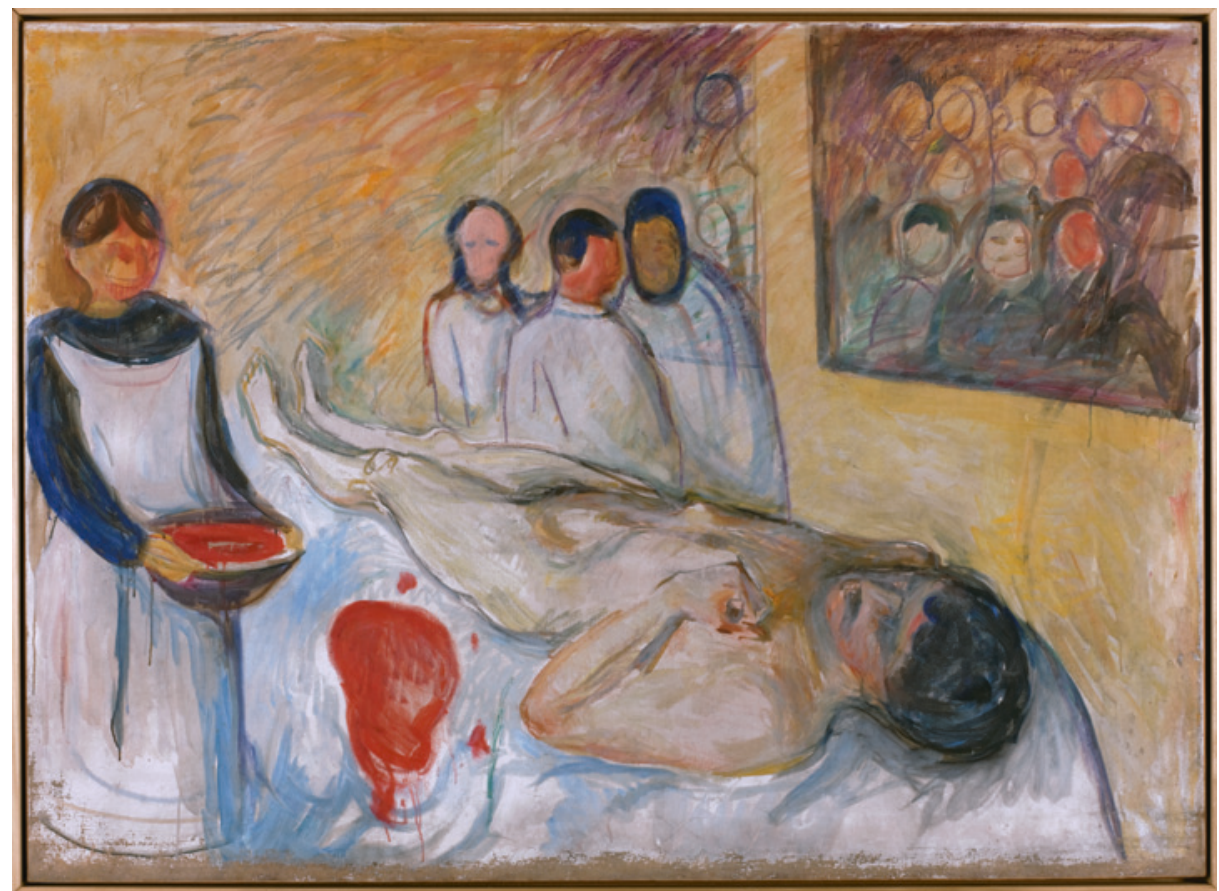

Figur 4 Edvard Munch: På operasjonsbordet, 1902-03. Olje på lerret, $109 \times 149 \mathrm{~cm}$. Munchmuseet. Foto ( Munchmuseet

gått inn gjennem venstre langfingers rotledd på tommelfingersiden, og ut på ulnarsiden, derfra inn i 4de finger. I utgangsåpningen sees et par bensplinter å stikke frem» (fig 3).

Neste dag ble Munch operert (4, fig 4). Han motsatte seg bruk av kloroform og fikk derfor bare lokalanestesi med kokain. Benfragmenter ble fjernet og såret tamponert. Han ble utskrevet etter ti dager «i bedring» (1, s. 249). Som sekvele ble tredje finger på venstre hånd betydelig forkortet. Senere smerteperioder minnet ham livet ut om dramaet 11. september 1902.

Jeg takker Munchmuseets sekretær Karen Lerheim og fotograf Ove Kvavik.

\section{Jacob Magne Klafstad (f. 1934)}

er lege og tannlege og spesialist i maxillo-facial kirurgi. Han har vært universitetslærer i oral kirurgi og røntgenologi.

Forfatter har fylt ut ICMJE-skjemaet og oppgir ingen interessekonflikter.

\section{Litteratur}

1. Næss A. Munch, en biografi. Oslo: Gyldendal, 2004.

2. Bjørnstad K. Historien om Edvard Munch. Oslo: Gyldendal, 1993.

3. Norges leger. Oslo: Den norske legeforening, 1996.

4. Woll G. Edvard Munch samlede malerier. Oslo: Cappelen Damm, 2008.

Mottatt 1.2. 2017, første revisjon innsendt 28.2. 2017, godkjent 13.3. 2017. Redaktør: Kari Tveito. 